\title{
Nasal versus temporal preretinal vasoproliferation in retinopathy of prematurity
}

\author{
I NISSENKORN, I KREMER, S COHEN, AND I BEN-SIRA
}

From the Department of Ophthalmology, Beilinson Medical Center, Petah Tiqva, Sackler School of Medicine, Tel Aviv University, Israel

SUMMARY Nasal preretinal neovascularisations have been observed to develop at least two weeks earlier than those on the temporal side in more than a third of premature babies with retinopathy of prematurity (ROP) stage 3, weighing between 690 and $1030 \mathrm{~g}$. All these babies were assigned for cryotherapy. This interesting observation is discussed in relation to retinal vascular development and the pathogenesis of ROP.

The embryonic retina remains avascular until the fourth month of fetal development. ${ }^{1-3}$ At 4 months spindle cells are found in Bergmeister's precapillary cone surrounding the walls of the hyaloid artery and its veins. ${ }^{3}$ From the walls of the venous channels on either side of the hyaloid artery the spindle cells undergo active mitosis and begin their migration into the nerve fibre layer at the 16th week of embryonal life. ${ }^{4}$ These undifferentiated spindle cells continue to advance towards the ora serrata, so that they always form the peripheral margin (vanguard) of the developing capillaries. ${ }^{56}$ The capillary bed with the vanguard of spindle cells appears to spread centrifugally, so that by the eighth fetal month the primitive capillary network extends almost to the ora serrata nasally but only to the equator temporally..$^{134}$ It is therefore obvious that through all stages of retinal development the avascular area of the developing temporal retina is much larger than the avascular area of the nasal retina. Consequently we should expect that in stage 3 retinopathy of prematurity (ROP) the active neovascular proliferations would be much more extensive and appear earlier in the temporal retina than in the nasal retina.

We present here an interesting observation on the development of nasal versus temporal vasoproliferative disease in ROP stage 3, found in premature babies born between the 26th and 28th weeks of gestation and with a birth weight less than $1250 \mathrm{~g}$.

Correspondence to I Kremer, MD, Department of Ophthalmology, Beilinson Medical Center, Petah Tiqva 49100, Israel.

\section{Materials and methods}

During the years 1985-7, 85 premature babies weighing under $1250 \mathrm{~g}$, born at the age of 28 weeks or less, were examined in the Neonatal Intensive Care Unit (NICU). The first fundus examination was performed at the age of 3 to 4 weeks. When the avascular area was found to be located in Zone I or II, the subsequent examinations were performed at least once a week. When ROP stage 3 (moderate) was diagnosed, cryotreatment was performed according to a protocol described by Ben-Sira et al. ${ }^{78}$

\section{Results}

Seventeen out of 85 premature babies $(20 \%)$ were found to have ROP stage 3 and subsequently underwent cryotherapy. In six of the 17 cryotreated babies (35\%) with ROP stage 3 the vasoproliferative disease was found to begin at least two weeks earlier in the nasal side of the retina than the temporal side (Table 1). Five of the six babies weighed less than $1000 \mathrm{~g}$ and one weighed $1030 \mathrm{~g}$. In five babies cryotherapy was performed first on the nasal retina and subsequently, owing to progression of the active vasoproliferative disease temporally, on the temporal side. In only one baby was the vasoproliferative disease confined to the nasal retina, while ROP stage 2 only was noted on the temporal side (Table 1). Cryotherapy was therefore applied to the nasal avascular retina and not to the temporal side. No difference was found in the 
Table 1 Timing and extent of nasal versus temporal ROP stage 3

\begin{tabular}{|c|c|c|c|c|c|}
\hline \multirow[t]{2}{*}{ Case } & \multirow[t]{2}{*}{$\begin{array}{l}\text { Weight } \\
\text { (g) }\end{array}$} & \multicolumn{2}{|c|}{$\begin{array}{l}\text { Gestational Eyes } \\
\text { age (weeks) }\end{array}$} & \multicolumn{2}{|c|}{$\begin{array}{l}\text { ROP timing (weeks after } \\
\text { birth), stage } 3\end{array}$} \\
\hline & & & & $\begin{array}{l}\text { Nasal } \\
\text { side }\end{array}$ & $\begin{array}{l}\text { Temporal } \\
\text { side }\end{array}$ \\
\hline 1 & 750 & 26 & Both & 4 & 6 \\
\hline 2 & 1030 & 27 & Both & 6 & 8 \\
\hline 3 & 990 & 28 & Both & 4 & 7 \\
\hline 4 & 690 & 28 & Both & 5 & 8 \\
\hline 5 & 910 & 26 & Both & 6 & 8 \\
\hline 6 & 860 & 27 & Both & 6 & $7^{*}$ \\
\hline
\end{tabular}

*Stage 2 only.

clinical course of ROP stage 3 whether it started in the nasal retina or the temporal. Moreover, vasoproliferative disease in the nasal retina was found to regress after cryotherapy in the same manner as it did on the temporal side.

\section{Discussion}

Cogan ${ }^{9}$ and Patz $\mathrm{z}^{10}$ have shown that at 8 months of embryonic life the retina is completely vascularised only in the nasal periphery, whereas the temporal periphery is not completely vascularised until shortly after birth of the full-term infant. At the embryonal age of 8 months the developing capillaries have just reached the equator in the temporal retina (Fig. 1). Since the temporal periphery is the last part of the retina to become vascularised, the temporal retina has larger ischaemic areas than the nasal retina. ${ }^{3}$ This pattern of vascularisation probably explains the greater susceptibility of the temporal retina to ROP and may even explain the occasional case of ROP occurring in the full-term infant's temporal retina."

Extensive animal studies have shown that the retinal vessels are susceptible to oxygen damage only when the retina is incompletely vascularised. ${ }^{12-15}$ In addition the premature baby's retinal vasculature was found to be vulnerable to many other noxious factors which may be associated with ROP. ${ }^{15-18}$

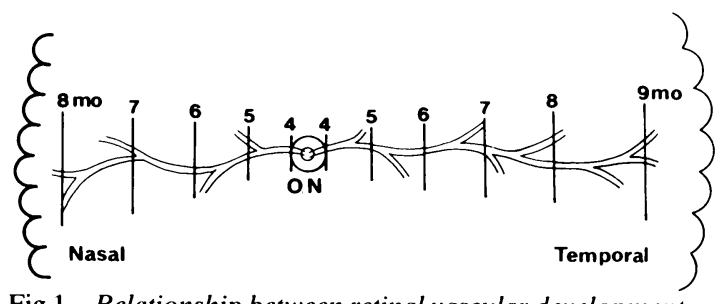

Fig 1 Relationship between retinal vascular development and retinal topographical anatomy. $O N=$ optic nerve.
We would therefore expect that a premature baby born before the 28 th week of gestation, and weighing less than $1250 \mathrm{~g}$, would develop more extensive ischaemic vasoproliferative disease, and much earlier on the temporal than the nasal retina. It is an interesting fact that in more than a third of the cases reported here $(35 \%)$ ROP stage 3 with confluent preretinal neovascularisation developed at least two weeks earlier in the nasal retina than the temporal. All these babies except one weighed less than $1000 \mathrm{~g}$. Later on, following cryoablation of the nasal retina, the vasoproliferative disease progressed to the temporal side, and was subsequently treated by further cryoablation in all babies except one. In the last baby ROP of the temporal retina remained at stage 2 , and there was therefore no indication for cryotherapy. In agreement with our findings, Fielder et al reported that the first visible changes of acute ROP can often be found in the nasal retina, particularly in the more immature baby. ${ }^{14-211}$

Unfortunately we cannot find any firm explanation for this unexpected observation. It should be stressed that ROP is a multifactorial disease, ${ }^{1 \times 21}$ whose pathogenesis is still incompletely understood. It may well be that peripheral retinal avascularity and subsequent ischaemia are not the only pathogenic factors. According to other hypotheses, such as the "spindle cell theory" ${ }^{\prime \prime}$ as well as that of tissue oxygen radicals, ${ }^{1 \times 21}$ the temporal retina should have no priority as the 'place of less resistance.'

\section{References}

1 Ashton $\mathrm{N}$. Retinal angiogenesis in the human embryo. Br Med Bull 1970; 26: 103-6.

2 Kuwabara T, Cogen DG. Studies of retinal vascular patterns. Part I. Normal architecture. Arch Ophthalmol 1960); 64: 9(14-11.

3 Michaelson IC. The mode of development of the vascular system of the retina, with some observations on its significance of certain retinal diseases. Trans Ophthalmol Soc UK 1948; 68: 157-80.

4 Ashton $\mathrm{N}$. The mode of development of the retinal vessels in man. In Cant JS, ed. William McKenzie Symposium on the Ocular Circulation in Health and Disease. St Louis: Mosby, 1969: 7-8.

5 Kretzer FL, Mehta RS, Johnson AT, Hunter DG, Brown ES, Hittner HM. Vitamin E protects against retinopathy of prematurity through action on spindle cells. Nature 1984; 309: 793-5.

6 Kretzer FL, Hittner HM. Human retinal development: relationship to the pathogenesis of retinopathy of prematurity. In: McPherson AR, Hittner HM, Kretzer FL, eds. Retinopathy of prematurity: current concepts and controversies. Toronto: Decker, 1986: 27-52.

7 Ben Sira I, Nissenkorn I. Treatment of acute retinopathy of prematurity with cryotherapy: the Beilinson experience. In: McPherson AR, Hittner HM, Kretzer, FL, eds. Retinopathy of prematurity. Toronto: Decker, 1986: 129-71.

8 Ben Sira I, Nissenkorn I, Grunwald E, Yassur Y. Treatment of acute retrolental fibroplasia by cryopexy. Br J Ophthalmol 1980; 64: $758-62$.

9 Cogan DG. Development and senescence of the human retinal vasculature. Trans Ophthalmol Soc UK 1963; 83: 465-89. 
10 Patz A. The role of oxygen in retrolental fibroplasia. Pediatrics 1957: 19: 504-24.

11 Brockhurst RJ, Chishti MI. Cicatricial retrolental fibroplasia: its occurrence without oxygen administration and in full-term infants. Graefes Arch Clin Exp Ophthalmol 1975; 195: 113-28.

12 Ashton N, Ward B, Serpell G. Effect of oxygen on developing retinal vessels with particular reference to the problem of retrolental fibroplasia. Br J Ophthalmol 1954: 38: 397-432.

13 Ashton N. Oxygen and the growth and development of retinal vessels: in vivo and in vitro studies. Am J Ophthalmol 1966; 62: 412-35.

14 Patz A, Eastham A, Higginbotham DH, Kleh T. oxygen studies in retrolental fibroplasia. II. The production of the microscopic changes of retrolental fibroplasia in experimental animals. Am J Ophthalmol 1953; 36: 1511-22.

15 Patz A, Hoeck LE, DeLaCruz E. Studies on the effect of high oxygen administration in retrolental fibroplasia: a nursery observation. Am J Ophthalmol 1952: 35: 1248-52.

16 Bossi E, Koenher F, Flury B, Zulall FM. Retinopathy of prematurity: a risk factor analysis with univariate and multivariate statistics. Helv Paediatr Acta 1984; 39: 307-17.
17 Glass P. Avery GB, Subramanian KN, Keys MP, Sostek AM, Friendly DS. Effect of bright light in the hospital nursery on the incidence of retinopathy of prematurity. N Engl J Med 1985; 313: 401-4.

18 Hammer ME, Muilen PW, Ferguson JG. Logistic analysis of risk factors in acute retinopathy of prematurity. $A M J$ Ophthalmol 1986; 102: 1-6.

19 Fielder AR, Ng YK, Levene MI, Shaw DE. Retinopathy prematurity: age at onset and the initial site of retinal involvement. A preliminry report. In: Ben Ezra E, Ryan S, Glaser BM, Murphy RP, eds. Ocular circulation and neovascularisation. Dordrecht: Nijhoff Junk, 1987: 147-53.

20 Fielder AR, Ng YK, Shaw DE, Levene MI. Retinopathy of prematurity: natural history. Invest Ophthalmol Vis Sci 1988; 29: (suppl 121).

21 Ben Sira I, Nissenkorn I, Kremer I. Retinopathy of prematurity (review). Surv Ophthalmol 1988: 33: 1-16.

Accepted for publication 15 April 1989. 